\title{
Carotid Artery Intimal Medial thickness in Diabetic and Non-Diabetic Subjects in Central Kerala
}

\author{
Sholy K Vareed ${ }^{\circledR 1}$, Don Paul Mathew ${ }^{\circledR 2}$, P Suresh ${ }^{\circ 3}$ \\ ${ }^{1}$ Associate Professor, Department of Radio diagnosis, SNIMS, Chalakka, Ernakulam, India, ${ }^{2}$ Assistant Professor, Department of Radio diagnosis, SNIMS, Chalakka, \\ Ernakulam, India, ${ }^{3}$ Professor, Department of Medicine, SNIMS, Chalakka, Ernakulam, India.
}

\section{Abstract}

Background: Increase in intimal medial thickness (IMT) of the carotid arteries is contemplated as a guide to atherosclerotic vascular disease and subclinical organ damage and foretell cardiovascular disease. The study aimed to analyse IMT in non-diabetic and diabetic subjects. Subjects and Methods: There were 105 diabetic and 95 non-diabetic subjects in this study. Common carotid artery (CCA) IMT was calculated using a linear probe of a high-resolution ultrasound medical system. Results: Diabetic subjects $(0.95 \mathrm{~mm})$ showed significantly higher mean intimal medial thickness (IMT) when compared non-diabetic subjects $(0.85 \mathrm{~mm})(\mathrm{p}<0.05)$. Correlation of IMT was seen with age, total cholesterol, triglycerides, HDL \& LDL cholesterol and systolic blood pressure (SBP) in diabetic subjects. Total cholesterol, SBP and diastolic blood pressure (DBP) showed a correlation with IMT in the non-diabetic subjects. Age, total cholesterol, SBP, and diabetes were independent risk factors for intimal medial thickness in multivariate linear regression analysis. Conclusion: Higher intimal medial thickness was seen in diabetic subjects when compared to non-diabetic subjects. We conclude that age, total cholesterol, SBP and duration of diabetes showed a significant correlation with IMT. IMT can be considered as a screening tool in diabetic patients for the early detection of atherosclerosis.

Keywords: Diabetes Mellitus, Ultrasonography, Atherosclerosis.

Corresponding Author: Don Paul Mathew, Assistant Professor, Department of Radio diagnosis, SNIMS, Chalakka, Ernakulam, India. E-mail: donpaulm@yahoo.com

Received: 20 October 2020

Published: 31 December 2020

\section{Introduction}

The intima-media thickness (IMT) is equivalent to the intimamedia complex, which includes smooth muscle, connective tissue and endothelial cells, the area of fat deposition in atherosclerosis. Carotid IMT (CIMT) is used as a noninvasive and surrogate measure of atherosclerosis. ${ }^{[1-9]}$ Good correlation of subsequent progress to myocardial infarction and stroke with IMT measurements is seen. ${ }^{[10,11]}$ Studies have shown that for each $0.1-\mathrm{mm}$ rise in carotid IMT, the relative risk of cardiovascular disease rises by $15 \%$ and that of cerebrovascular disease by $18 \% .^{[12]}$ CIMT also correlates with clinically established cardiovascular disease and the Framingham Score. ${ }^{[13-17]}$ In type 2 diabetic patients' duration of diabetes, hypertension, hyperglycemia, dyslipidemia, and smoking have been identified as significant risk factors for stroke. ${ }^{[18]}$ Further IMT measurement is non-invasive, inexpensive, and easily available and carries no risk for the patient. A high prevalence of premature coronary artery disease and diabetes is seen in Asian Indians. ${ }^{[19-23]}$ India is among the leaders in a number of diabetic patients in the world. ${ }^{[24]}$ Diabetes leads to atherosclerotic vascular disease and complications like coronary artery disease (CAD) and stroke. This study looks into IMT in diabetic and non-diabetic subjects in central Kerala.

\section{Subjects and Methods}

This is a cross-sectional study that included 200 participants. The criteria used for the diagnosis of diabetes were fasting blood sugar (FBS) higher than $\geq 126 \mathrm{mg} \%$, a postprandial blood sugar (PPBS) higher than $\geq 200 \mathrm{mg} \%$ and random plasma glucose $\geq 200 \mathrm{mg} \%$. Non-diabetics were those who had a normal FBS test and none of the items above. The present work was undertaken in collaboration between the Department of Radiology and Medicine, SNIMS, Chalakka, during the period May 2017 to May 2020. After approval by the ethical committee, due consents were taken from the respective patients and guardians of the patients. Subjects were selected from inpatient and outpatient clinics of the medicine department. A thorough medical history and complete physical examination of all patients were done followed by investiga- 


\begin{tabular}{llllll|}
\hline \multicolumn{6}{|c|}{ Table 1: Comparison of IMT based on diabetic status } \\
\hline $\begin{array}{l}\text { Diabetic } \\
\text { status }\end{array}$ & Mean & SD & N & T & P \\
$\begin{array}{l}\text { Non- } \\
\text { diabetic }\end{array}$ & 0.085 & 0.024 & 105 & 2.97 & 0.003 \\
Diabetic & 0.095 & 0.023 & 95 & & \\
\hline
\end{tabular}

tions including, FBS, PPBS, lipid profile and ultrasonography for CIMT measurement.

\section{$\underline{\text { Intimal medial thickness assessment }}$}

The IMT thickness of the carotid arteries was calculated using a high-resolution ultrasonography machine (Philips Affiniti 50 ) having a linear array transducer and a frequency range of 7- $15 \mathrm{MHz}$. Patients were positioned with the head slightly extended and turned towards the opposite side of the carotids being assessed. To assess CIMT, far-wall IMT measurements were taken, because they are viewed as more accurate than near-wall measurements. The measurement is made between the two bright lines made by blood-intima interface and mediaadventitia junction as the far and near-wall respectively. CIMT of both sides was assessed at 3 sites (point of maximum thickness, and at sites $1 \mathrm{~cm}$ proximal and distal to it and free from plaques) on the sagittal plane. The mean CIMT was defined as the mean IMT of the right and left common carotid arteries, calculated from 3 readings on both sides. All measurements were assessed by experienced radiologists who were blinded to the diabetic status of the subjects.

\section{Statistical analysis}

The Independent t-test was used to compare quantitative parameters between categories. A Chi-square test was used to the association between categorical variables. Karl Pearson Correlation Coefficient was used to find our relationship of IMT with age, serum cholesterol, serum triglycerides, HDL cholesterol, SBP and DBP as independent variables. Multiple linear regressions were done to find the independent influence of selected variables on IMT. For every statistical analysis, $\mathrm{p}<0.05$ was taken as the point for statistical significance. Statistical analyses were done using statistical software, IBM SPSS version 20.0

\section{Results}

Mean CIMT in the non-diabetic group was $0.85 \mathrm{~mm}$ and in the diabetic group was $0.95 \mathrm{~mm}$. The range of CIMT values in non-diabetics was $0.4-1.7 \mathrm{~mm}$ and in diabetics, $0.4-1.85$ $\mathrm{mm}$.

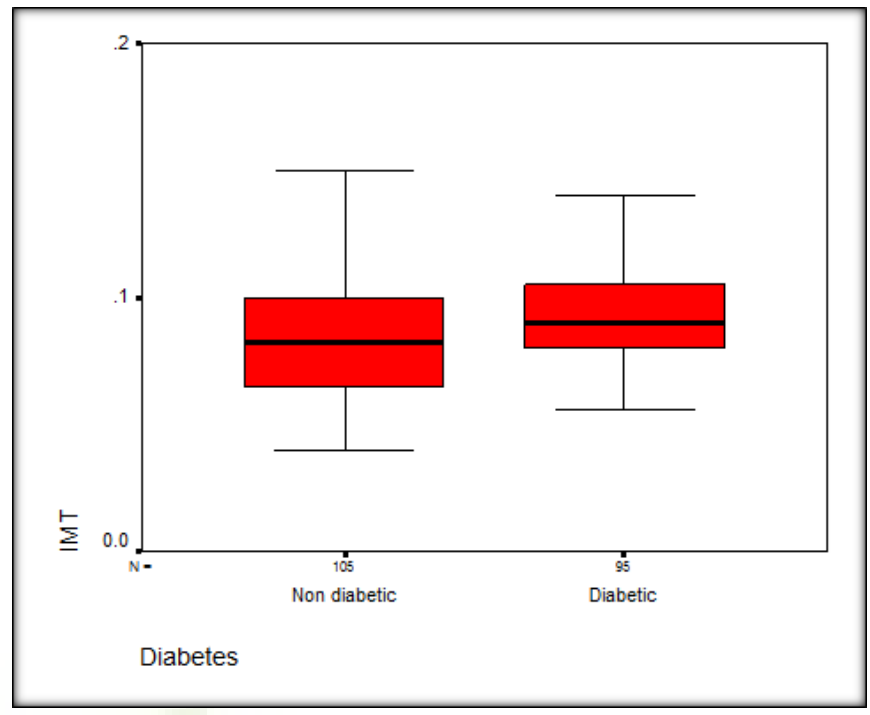

Figure 1: Box plot for CIMT based on diabetic status

The diabetic group had higher total cholesterol, triglycerides, HDL and LDL than non-diabetic subjects but only total cholesterol showing a significant difference

Increased CIMT was seen in the diabetic group compared with a non-diabetic group in both gender in our study, but only the non-diabetic group showing a significant difference.

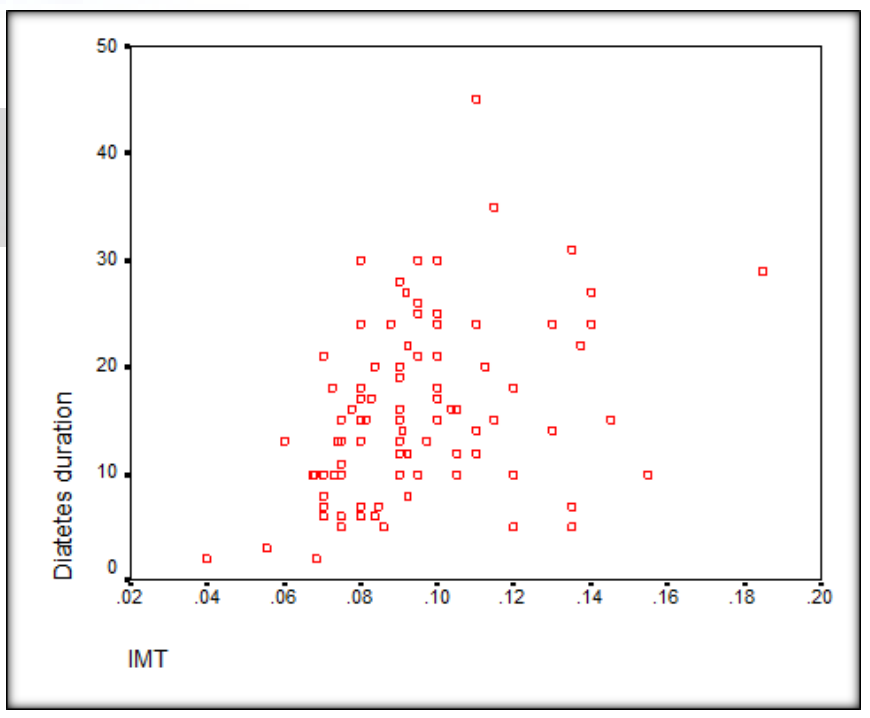

Figure 2: Scatter diagram for diabetes and CIMT $(r=$ $0.366, p<0.01)$

In the non-diabetic group cholesterol, SBP and DBP showed a positive correlation with IMT whereas, in the diabetic group, age, cholesterol, triglycerides, LDL and HDL cholesterol, 


\begin{tabular}{lllllllll}
\hline \multicolumn{7}{l}{ Table 2: Comparison of lipid profile based on diabetic status } \\
\hline & Non-diabetic & Diabetic & & & & T & P \\
& Mean & SD & N & Mean & SD & N & & \\
CHO & 195.4 & 37.6 & 105 & 205.7 & 34.9 & 95 & 2 & 0.047 \\
TRI & 142.6 & 39.1 & 105 & 148.8 & 32.9 & 95 & 1.2 & 0.230 \\
HDL & 35.4 & 8.8 & 105 & 37.1 & 5.7 & 95 & 1.56 & 0.120 \\
LDL & 125.9 & 28.8 & 105 & 129.2 & 27.4 & 95 & 0.82 & 0.412 \\
\hline
\end{tabular}

\begin{tabular}{|c|c|c|c|c|c|c|}
\hline Diabetes & Sex & Mean & SD & $\mathbf{N}$ & $T$ & $\mathbf{P}$ \\
\hline \multirow[t]{2}{*}{ Non-diabetic } & Male & 0.091 & 0.025 & 47 & 2.31 & 0.023 \\
\hline & Female & 0.080 & 0.021 & 58 & & \\
\hline \multirow[t]{2}{*}{ Diabetic } & Male & 0.097 & 0.021 & 48 & 1.05 & 0.299 \\
\hline & Female & 0.092 & 0.025 & 47 & & \\
\hline
\end{tabular}

\begin{tabular}{|c|c|c|c|c|}
\hline & \multicolumn{2}{|c|}{ Diabetic } & \multicolumn{2}{|c|}{ Non-diabetic } \\
\hline & $\mathbf{R}$ & $\mathbf{p}$ & $\mathbf{r}$ & $\mathbf{P}$ \\
\hline $\mathrm{CHO}$ & 0.522 & $\mathrm{p}<0.01$ & 0.314 & 0.002 \\
\hline TRI & 0.407 & $\mathrm{p}<0.01$ & 0.134 & 0.195 \\
\hline HDL & -0.411 & $\mathrm{p}<0.01$ & -0.134 & 0.196 \\
\hline LDL & 0.471 & $\mathrm{p}<0.01$ & 0.152 & 0.142 \\
\hline Age & 0.43 & $\mathrm{p}<0.01$ & 0.191 & 0.063 \\
\hline SBP & 0.319 & 0.001 & 0.409 & $\mathrm{p}<0.01$ \\
\hline DBP & 0.035 & 0.723 & 0.326 & 0.001 \\
\hline
\end{tabular}

SBP, and duration of diabetes showed a positive correlation with CIMT

The mean CIMT of the non-diabetic group in normotensive and hypertension subjects was $0.73 \mathrm{~mm}$ and $0.90 \mathrm{~mm}$, respectively. In the diabetic group, normotensive and hypertension subjects had the mean CIMT values of $0.85 \mathrm{~mm}$ and $0.98 \mathrm{~mm}$ respectively

Multivariate linear regression analysis was done including details of both diabetic and non-diabetic groups and counting diabetes as an independent variable. Age cholesterol, HDL cholesterol, SBP and diabetes exhibited an association with IMT

\section{Discussion}

CIMT is regarded to be a non-invasive marker of atherosclerotic vascular disease, ${ }^{[1-3]}$ coronary artery disease and recurrent ischemic stroke. ${ }^{[25-29]}$ The earliest indication of atherosclerotic vascular disease is seen as a mild rise in IMT, which progresses to vascular plaque formation and stenosis.
Carotid atherosclerosis, even without significant stenosis, is linked with an increased risk of cerebrovascular disease. Increased IMT in type 2 diabetes can be explained secondary to glucose toxicity to the endothelial layer and glycosylation processes, which is concurred by the greater levels of plasma glucose and $\mathrm{HbA} 1 \mathrm{c}$ in diabetic subjects. ${ }^{[30]}$ IMT is also used to evaluate the response to various intervention therapies in atherosclerotic vascular disease. ${ }^{[31-33]}$ It has been postulated that carotid and cerebral arteries and the aorta go through atherosclerotic vascular disease almost at the same time as coronary arteries. ${ }^{[34]}$ Racial differences in CAD morbidity and mortality have been highlighted in previous studies. ${ }^{[19,20,35]}$ Differences between family history of CAD and intima-media thickness in whites and blacks were found in ARIC Study. ${ }^{[36]}$ The importance assessment of intima-media thickness in diverse geographies is highlighted by these ethnic differences. This study assesses CIMT in the central Kerala population. Increased prevalence rates of CAD and diabetes was noted in the south Indian population in various studies. ${ }^{[19,20,37,38]}$ The prevalence of the peripheral vascular disease is low compared to coronary artery disease in the Indian population. ${ }^{[39]}$ 


\begin{tabular}{|lllllll}
\hline \multicolumn{2}{l}{ Table 5: Comparison of CIMT with hypertension among diabetic and non-diabetic patients } & & \\
\hline Diabetes & Hypertension & Mean & SD & N & T & 3.36 \\
Non-diabetic & Absent & 0.073 & 0.016 & 30 & 75 & 0.001 \\
& Present & 0.090 & 0.025 & 22 & 2.23 & 0.028 \\
\hline \multirow{2}{*}{ Diabetic } & Absent & 0.085 & 0.021 & 73 & \\
\hline
\end{tabular}

Table 6: Independent predictors of CIMT

\begin{tabular}{lllll|l}
\hline & B & Std. Error & T & P & $\mathbf{R}^{2}$ \\
Age & 0.00041 & 0.00012 & 3.35 & $\mathrm{p}<0.01$ & 0.389 \\
\hline CHO & 0.00022 & 0.00004 & 5.69 & $\mathrm{p}<0.01$ & $\mathrm{p}<0.01$ \\
\hline HDL & -0.00066 & 0.00018 & 3.57 & $\mathrm{p}<0.01$ & 0.002 \\
\hline SBP & 0.00023 & 0.00006 & 3.92 & 3.17 & 0.1 \\
\hline Diabetes & 0.00868 & 0.00274 & & \\
\hline
\end{tabular}

This is an important point of differences in macrovascular disease among Indians and increases the significance of the study on IMT in this population. Increased CIMT is noted in the diabetic group compared with the non-diabetic group in both genders in our study. Females had lesser mean CIMT in comparison to males possibly due to the protecting effect of feminine hormones. Significantly increased IMT in males as compared to females was reported by Kraml et al. ${ }^{[40]}$ Total cholesterol, SBP and DBP showed a statistically significant correlation with CIMT in the non-diabetic group. In the diabetic group, age, total cholesterol, triglycerides, HDL and LDL cholesterol, SBP, DBP and duration of diabetes showed a significant correlation with CIMT. Age, serum cholesterol, HDL cholesterol, SBP and diabetes showed an association with CIMT in multivariate linear regression analysis. An increase in CIMT with the duration of diabetes was seen in our study with a significant $p$-value of $<0.01$. Increased CIMT is noted in the diabetic group as compared with the non-diabetic group in both hypertensive and normotensives in our study. LDL particles because of their adhesion to glycosaminoglycan's in the endothelial basement membrane, causes injury to the endothelium and smooth muscle because of high susceptibility to scavenger receptors on macrophages leading to increased risk of atherosclerotic diseases. ${ }^{[41]}$ Correlation between triglycerides and IMT in diabetics was seen in this study. A good association between triglycerides levels and the progression of IMT has been reported. ${ }^{[41,42]}$ HDL cholesterol was established to be an independent predictor of CIMT values in this study in concurrence with other studies. ${ }^{[3,44]}$ Cholesterol was found to be an independent risk factor for CIMT and showed a correlation with IMT in both diabetics and non-diabetics in our study. Pronounced adverse effects of diabetes and cholesterol on atherosclerotic vascular disease amongst Asian Indians were proposed as a reason for observed increased rates of CVD. ${ }^{[45]}$ Our study showed a correlation of
IMT with age in diabetics but not in non-diabetics. This could be due to the predominant older age group in our study.

A higher prevalence of atherosclerotic vascular disease is noted in diabetic patients and carotid atherosclerotic vascular disease sets in around 2-3 decades earlier than non-diabetic subjects. ${ }^{[2]}$ Various studies showed different risk factors for greater CIMT in diabetic subjects. Kawamori et al reported that smoking, duration of diabetes, age, hyperlipidemia and hypertension were independently associated with CIMT in diabetic patients. ${ }^{[2]}$ A study by Geroulakos et al showed that of the likely risk factors none was associated with CIMT in diabetic patients. ${ }^{[46]}$ Merrin et al proposed only age to be an independent risk factor for CIMT. ${ }^{[4]}$ Yamasaki et al found that diabetic mellitus and age to accentuate the atherosclerotic process in the carotid arteries. ${ }^{[48](48)}$ Kanters et al proposed that of the potential risk factors none of the variables were associated with CIMT in Type II diabetes mellitus and identified $\mathrm{HbAlc}$ and age as the risk factors for CIMT in Type I diabetes mellitus. ${ }^{[49]}$ IMT also showed predictive power for the risk of stroke and CAD in studies in the elderly population. ${ }^{[10,50]}$ The limitations of this study were relatively small sample size, single-center data, and operator variability in IMT measurement.

\section{Conclusion}

We conclude that age, total cholesterol, duration of diabetes and blood pressure exhibited a significant correlation with CIMT. IMT can be considered as a screening aid in diabetic subjects for the early detection of atherosclerosis. Supplemental prospective studies are advocated to assess the retrogression of CIMT with the management of these risk factors among diabetic patients. 


\section{References}

1. P P. Ultrasound B-Mode Imaging For Arterial Wall Thickness Measurement. Atheroscler Rev. 1984;12:177-184.

2. Kawamori R, Yamasaki Y, Matsushima H, Nishizawa H, Nao $\mathrm{K}$, Hougaku H, et al. Prevalence of Carotid Atherosclerosis in Diabetic Patients Ultrasound high-resolution B-mode imaging on carotid arteries. Diabetes Care. 1992;15:1290-1294. Available from: https://dx.doi.org/10.2337/diacare.15.10.1290.

3. Grobbee DE, Bots ML. Carotid artery intima-media thickness as an indicator of generalized atherosclerosis. J Int Med. 1994;236(5):567-573. Available from: https://dx.doi.org/10. 1111/j.1365-2796.1994.tb00847.x.

4. Ebrahim S, Papacosta O, Whincup P, Wannamethee G, Walker M, Nicolaides AN, et al. Carotid Plaque, Intima Media Thickness, Cardiovascular Risk Factors, and Prevalent Cardiovascular Disease in Men and Women. Stroke. 1999;30(4):841-850. Available from: https://dx.doi.org/10. 1161/01.str.30.4.841.

5. Cupini LM, Pasqualetti P, Diomedi M, Vernieri F, Silvestrini M, Rizzato B. Carotid Artery Intima-Media Thickness and Lacunar Versus Nonlacunar Infarcts. Stroke. 2002;33(3):689694. Available from: https://dx.doi.org/10.1161/hs0302. 103661.

6. Vemmos KN, Tsivgoulis G, Spengos K, Papamichael CM, Zakopoulos N, Daffertshofer M, et al. Common Carotid Artery Intima-Media Thickness in Patients with Brain Infarction and Intracerebral Haemorrhage. Cerebrovasc Dis. 2004;17(4):280 286. Available from: https://dx.doi.org/10.1159/000077338.

7. Touboul PJ, Elbaz A, Koller C, Lucas C, Adraï V, Chédru F, et al. Common Carotid Artery Intima-Media Thickness And Brain Infarction: The Etude Du Profil Genetique De L'infarctus Cerebral (GENIC) Case-Control Study. Circulation. 2000;102(3):313-321. Available from: https://doi.org/10. 1161/01.cir.102.3.313.

8. Matsumoto K, Sera Y, Nakamura H, Ueki Y, Miyake S. Correlation between common carotid arterial wall thickness and ischemic stroke in patients with type 2 diabetes mellitus. Metabolism. 2002;51(2):244-247. Available from: https://dx. doi.org/10.1053/meta.2002.28971.

9. Davis PH, Dawson JD, Riley WA, Lauer RM. Carotid IntimalMedial Thickness Is Related to Cardiovascular Risk Factors Measured From Childhood Through Middle Age. Circulation. 2001;104(23):2815-2819. Available from: https://dx.doi.org/ 10.1161/hc4601.099486. doi:10.1161/hc4601.099486.

10. O'Leary DH, Polak JF, Kronmal RA, Manolio TA, Burke GL, Wolfson SK. Carotid-Artery Intima and Media Thickness as a Risk Factor for Myocardial Infarction and Stroke in Older Adults. N Engl J Med. 1999;340(1):14-22. Available from: https://dx.doi.org/10.1056/nejm199901073400103.

11. Hodis HN, Mack WJ, Labree L, Selzer RH, Liu CR, Liu $\mathrm{CH}$, et al. The Role Of Carotid Arterial Intima - Media Thickness In Predicting Clinical Coronary Events. Ann Intern Med. 1998;128(4):262-271. Available from: https://doi.org/10. 7326/0003-4819-128-4-199802150-00002.

12. Lorenz MW, Markus HS, Bots ML, Rosvall M, Sitzer M. Prediction of Clinical Cardiovascular Events With Carotid Intima-Media Thickness. Circulation. 2007;115:459-467.
Available from: https://dx.doi.org/10.1161/circulationaha.106. 628875.

13. Chambless LE, Folsom AR, Clegg LX, Sharrett AR, Shahar E, Nieto FJ, et al. Carotid Wall Thickness is Predictive of Incident Clinical Stroke: The Atherosclerosis Risk in Communities (ARIC) Study. Am J Epidemiol. 2000;151(5):478. Available from: https://dx.doi.org/10.1093/oxfordjournals.aje.a010233.

14. O'Leary DH, Polak JF, Kronmal RA, Kittner SJ, Bond MG, Wolfson SK, et al. Distribution and correlates of sonographically detected carotid artery disease in the Cardiovascular Health Study. The CHS Collaborative Research Group. Stroke. 1992;23:1752-1760. Available from: https://dx.doi.org/10. 1161/01.str.23.12.1752.

15. Touboul PJ, Labreuche J, Vicaut E, Amarenco P. Carotid Intima-Media Thickness, Plaques, and Framingham Risk Score as Independent Determinants of Stroke Risk. Stroke. 2005;36(8):1741-1745. Available from: https://dx.doi.org/10. 1161/01.str.0000174490.23495.57.

16. Yamasaki Y, Kodama M, Nishizawa H, Sakamoto K, Matsuhisa M, Kajimoto Y, et al. Carotid intima-media thickness in Japanese type 2 diabetic subjects: predictors of progression and relationship with incident coronary heart disease. Diabetes Care. 2000;23(9):1310-1315. Available from: https://dx.doi. org/10.2337/diacare.23.9.1310.

17. Bots ML, Hoes AW, Koudstaal PJ, Hofman A, Grobbee DE. Common Carotid Intima-Media Thickness and Risk of Stroke and Myocardial Infarction. Circulation. 1997;96(5):14321437. Available from: https://dx.doi.org/10.1161/01.cir.96.5. 1432.

18. Kawamori R, Yamasaki Y, Matsushima H, Nishizawa H, Nao K, Hougaku H, et al. Prevalence of Carotid Atherosclerosis in Diabetic Patients Ultrasound high-resolution B-mode imaging on carotid arteries. Diabetes Care. 1992;15(10):1290-1294. Available from: https://dx.doi.org/10.2337/diacare.15.10.1290.

19. MCKEIGUE P. Coronary heart disease in South Asians overseas: A review. J Clin Epidemiol. 1989;42(7):597-609. Available from: https://dx.doi.org/10.1016/0895-4356(89)90002-4.

20. Balarajan R. Ethnic differences in mortality from ischaemic heart disease and cerebrovascular disease in England and Wales. BMJ. 1991;302(6776):560-564. Available from: https: //dx.doi.org/10.1136/bmj.302.6776.560.

21. Beckles GL, Miller GJ, Kirkwood BR, Alexis SD, Carson DC, Byam NT. High total and cardiovascular disease mortality in adults of Indian descent in Trinidad, unexplained by major coronary risk factors. Lancet. 1986;327(8493):1298 1301. Available from: https://dx.doi.org/10.1016/s01406736(86)91221-3.

22. Balarajan R. Ethnic differences in mortality from ischaemic heart disease and cerebrovascular disease in England and Wales. BMJ. 1991;302(6776):560-564. Available from: https: //dx.doi.org/10.1136/bmj.302.6776.560.

23. Mather HM, Keen H. The Southall Diabetes Survey: prevalence of known diabetes in Asians and Europeans. BMJ. 1985;291(6502):1081-1084. Available from: https://dx.doi. org/10.1136/bmj.291.6502.1081.

24. King H, Aubert RE, Herman WH. Global Burden of Diabetes, 1995-2025: Prevalence, numerical estimates, and projections. Diabetes Care. 1995;21(9):1414-1445. Available from: https: 
//doi.org/10.2337/diacare.21.9.1414.

25. O'Leary DH, Polak JF, Kronmal RA, Manolio TA, Burke GL, Wolfson SK. Carotid-Artery Intima and Media Thickness as a Risk Factor for Myocardial Infarction and Stroke in Older Adults. N Engl J Med. 1999;340(1):14-22. Available from: https://dx.doi.org/10.1056/nejm199901073400103.

26. Geroulakos G, O'Gorman D, Nicolaides A, Sheridan D, Elkeles R, Shaper AG. Carotid intima-media thickness: correlation with the British Regional Heart Study risk score. J Intern Med. 1994;235(5):431-433. Available from: https://dx.doi.org/10. 1111/j.1365-2796.1994.tb01099.x.

27. Ebrahim S, Papacosta O, Whincup P, Wannamethee G, Walker M, Nicolaides AN, et al. Carotid Plaque, Intima Media Thickness, Cardiovascular Risk Factors, and Prevalent Cardiovascular Disease in Men and Women. Stroke. 1999;30:841-850. Available from: https://dx.doi.org/10.1161/ 01.str.30.4.841.

28. Hodis HN, Mack WJ, Labree L, Selzer RH, Liu CR, Liu $\mathrm{CH}$, et al. The Role Of Carotid Arterial Intima - Media Thickness In Predicting Clinical Coronary Events. Ann Intern Med. 1998;128(4):262-271. Available from: https://doi.org/10. 7326/0003-4819-128-4-199802150-00002.

29. Bots ML, Hoes AW, Koudstaal PJ, Hofman A, Grobbee DE. Common Carotid Intima-Media Thickness and Risk of Stroke and Myocardial Infarction. Circulation. 1997;96:1432-1437. Available from: https://dx.doi.org/10.1161/01.cir.96.5.1432.

30. Temelkova-Kurktschiev TS, Koehler C, Leonhardt W, Schaper F, Henkel E, Siegert G, et al. Increased intimal-medial thickness in newly detected type 2 diabetes: risk factors. Diabetes Care. 1999;22:333-338. Available from: https://dx.doi.org/10.2337/ diacare.22.2.333.

31. Migdalis IN, Gerolimou B, Kozanidou G, Hatzigakis SM, Karmaniolas KD. Effect of fosinopril sodium on early carotid atherosclerosis in diabetic patients with hypertension. J Med . 1997;28(5-6):371-380.

32. Migdalis IN, Gerolimou B, Kozanidou G, Voudouris G, Hatzigakis SM, Petropoulos A. Effect Of Gemfibrozil On Early Carotid Atherosclerotic Vascular Diseasein Diabetic Patients With Hyperlipidaemia. Int Angiol. 1997;16(4):258-61.

33. Minamikawa J, Tanaka S, Yamauchi M, Inoue D, Koshiyama H. Potent Inhibitory Effect of Troglitazone on Carotid Arterial Wall Thickness in Type 2 Diabetes. J Clin Endocrinol Metab. 1998;83(5):1818-1818. Available from: https://dx.doi.org/10. 1210/jcem.83.5.4932.

34. General findings of the International Atherosclerosis Project. Lab Invest. 1968;18(5):498-502.

35. RF G. Cardiovascular Disease In The United States : An Epidemiologic Overview. Cardiovasc Clin. 1991;21(3):3-16.

36. Bensen JT, Li R, Hutchinson RG, Province MA, Tyroler HA. Family history of coronary heart disease and preclinical carotid artery atherosclerosis in African Americans and whites: The ARIC study. Genet Epidemiol. 1999;16(2):165178. Available from: https://dx.doi.org/10.1002/(sici)10982272(1999)16:2<165::aid-gepi4>3.0.co;2-h.

37. Mohan V, Sandeep S, Deepa R, Shah B, Varghese C. Epidemiology Of Type 2 Diabetes: Indian Scenario. Indian J Med Res. 2007;136(4)::217-230.

38. Menon VU, Kumar KV, Gilchrist A, Sugathan TN, Sundaram KR, Nair V, et al. Prevalence of known and undetected diabetes and associated risk factors in central Kerala - ADEPS. Diabetes Res Clin Pract. 2006;74(3):289-294. Available from: https://dx.doi.org/10.1016/j.diabres.2006.03.025.

39. Mohan V, Premalatha G, Sastry NG. Peripheral vascular disease in non-insulin-dependent diabetes mellitus in South India. Diabetes Res Clin Pract. 1995;27(3):235-240. Available from: https://dx.doi.org/10.1016/0168-8227(95)01048-i.

40. Kraml P, Potocková J, Anděl M, Zvárová J, Stefek M. Sonographic measurement of intimal thickness of the common carotid artery in diabetics. Vnitr Lek. 1999;45(8):457-462.

41. Bokemark L, Wikstrand J, Attvall S, Hulthe J, Wedel H, Fagerberg B. Insulin resistance and intima-media thickness in the carotid and femoral arteries of clinically healthy 58-yearold men. The Atherosclerosis and Insulin Resistance Study (AIR). J Intern Med. 2001;249(1):59-67. Available from: https://dx.doi.org/10.1046/j.1365-2796.2001.00735.x.

42. Fan AZ. Metabolic Syndrome and Progression of Atherosclerosis among Middle-aged US Adults. J Atheroscler Thromb. 2006;13(1):46-54. Available from: https://dx.doi.org/10.5551/ jat.13.46.

43. Touboul PJ, Labreuche J, Bruckert E, Schargrodsky H, Prati P, Tosetto A, et al. HDL-C, triglycerides and carotid IMT: A metaanalysis of 21,000 patients with automated edge detection IMT measurement. Atherosclerosis. 2014;232:65-71. Available from: https://dx.doi.org/10.1016/j.atherosclerosis.2013.10.011.

44. Chambless LE. Risk Factors for Progression of Common Carotid Atherosclerosis: The Atherosclerosis Risk in Communities Study, 1987-1998. Am J Epidemiol. 2002;155(1):38-47. Available from: https://dx.doi.org/10.1093/aje/155.1.38.

45. Chow CK, McQuillan B, Raju PK, Iyengar S, Raju R, Harmer JA, et al. Greater adverse effects of cholesterol and diabetes on carotid intima-media thickness in South Asian Indians: Comparison of risk factor-IMT associations in two population-based surveys. Atherosclerosis. 2008;199(1):116-122. Available from: https://dx.doi.org/10.1016/j.atherosclerosis.2007.10.008.

46. Geroulakos G, Ramaswami G, Veller MG, Fisher GM, Renton S, Nicolaides A, et al. Arterial Wall Changes in Type 2 Diabetic Subjects. Diabetic Med. 1994;11(7):692-695. Available from: https://dx.doi.org/10.1111/j.1464-5491.1994.tb00334.x.

47. Merrin PK, Renton S, Fisher C, Henderson A, Richmond W, Nicholaides A, et al. Serum Lipids and Apolipoproteins and Their Relationship with Macrovascular Disease in Type 1 Diabetes. Diabetic Med. 1994;11(4):402-406. Available from: https://dx.doi.org/10.1111/j.1464-5491.1994.tb00293.x.

48. Yamasaki $Y$, Kawamori R, Matsushima $H$, Nishizawa $H$, Kodama M, Kajimoto Y, et al. Atherosclerotic Vascular Diseasein Carotid Artery Of Young IDDM Patients Monitored By Ultrasound High-Resolution B-Mode Imaging. Diabetes. 1994;43(5):634-643. Available from: https://doi.org/10.2337/ diab.43.5.634.

49. Kanters SDJM, Algra A, Banga JD. Carotid IntimaMedia Thickness in Hyperlipidemic Type I and Type II Diabetic Patients. Diabetes Care. 1997;20:276-280. Available from: https://dx.doi.org/10.2337/diacare.20.3.276. doi:10.2337/diacare.20.3.276.

50. Hofman A, Grobbee DE, Jong PTVMD, den Ouweland FAV. Determinants of disease and disability in the elderly: The 
Rotterdam elderly study. Eu J Epidemiol. 1991;7(4):403-422. Available from: https://dx.doi.org/10.1007/bf00145007.

Copyright: (C) the author(s), 2020. It is an open-access article distributed under the terms of the Creative Commons Attribution License (CC BY 4.0), which permits authors to retain ownership of the copyright for their content, and allow anyone to download, reuse, reprint, modify, distribute and/or copy the content as long as the original authors and source are cited.

How to cite this article: Vareed SK, Mathew DP, Suresh P. Carotid Artery Intimal Medial thickness in Diabetic and NonDiabetic Subjects in Central Kerala. Asian J. Med. Radiol. Res. 2020;8(2):99-105.

DOI: dx.doi.org/10.47009/ajmrr.2020.8.2.16

Source of Support: Nil, Conflict of Interest: None declared. 